\title{
Anti-Zika Virus Effects, Placenta Protection and Chemical Composition of Passiflora edulis Seeds Ethanolic Extract
}

\author{
Jadriane A. Xavier, ${ }^{\circledR \#, a}$ Jaqueline C. Santos, ${ }^{\#, b}$ Monique A. Vila Nova, ${ }^{b}$ Camilla M. Gonçalves, ${ }^{b}$ \\ Karen S. C. Borbely, ${ }^{\oplus b, c}$ Keyla S. N. Pires, ${ }^{b}$ Flávia A. R. dos Santos, ${ }^{\circledR a}$ Iara B. Valentim, ${ }^{\circledR d}$ \\ Júnia H. P. Barbosa, ${ }^{a}$ Felipe C. da Silva, ${ }^{a}$ Josué C. C. Santos, ${ }^{\circledR a}$ Danielle R. Pinho, ${ }^{e}$ \\ Norberto P. Lopes, ${ }^{\oplus e}$ Alexandre U. Borbely ${ }^{\circledR * b}$ and Marília O. F. Goulart ${ }^{\circledR *, a}$ \\ ${ }^{a}$ Instituto de Química e Biotecnologia, Universidade Federal de Alagoas (UFAL), \\ 57072-970 Maceió-AL, Brazil \\ ${ }^{b}$ Laboratório de Biologia Celular, Instituto de Ciências Biológicas e da Saúde, \\ Universidade Federal de Alagoas (UFAL), 57072-970 Maceió-AL, Brazil \\ ${ }^{c}$ Faculdade de Nutrição, Universidade Federal de Alagoas (UFAL), \\ 57072-970 Maceió-AL, Brazil \\ 'Instituto Federal de Educação, Ciência e Tecnologia de Alagoas (IFAL), \\ Rua Mizael Domingues, 75, Centro, 57020-600 Maceió-AL, Brazil \\ ${ }^{e}$ Núcleo de Pesquisas em Produtos Naturais e Sintéticos, Departamento de Ciências Biomoleculares, \\ Faculdade de Ciências Farmacêuticas de Ribeirão Preto (FCFRP-USP), \\ Universidade de São Paulo, 14040-900 Ribeirão Preto-SP, Brazil
}

\begin{abstract}
Various beneficial biological activities have been reported for passion fruit (Passiflora edulis), grown in tropical and subtropical regions. However, no study has yet demonstrated its action against the Zika virus (ZIKV) infection. The present study aimed to investigate the anti-ZIKV of the ethanolic passion fruit seed extract (PFSE), from which, liquid chromatography tandem mass spectrometry (LC-MS/MS) analysis allowed to putatively annotate the occurrence of piceatannol, astringin, scirpusin $\mathrm{A}$, scirpusin $\mathrm{B}$, isookanin-7- $O$-glucoside and naringenin-7- $O$-glucoside, two quadranguloside derivatives, tyrosine, and phenylalanine. PFSE is well tolerated by cell lines (Vero E6 and HTR-8/SVneo) and tissue explants from the human placenta. With 1- and 24-h treatments, PFSE consistently reduced the viral load and NS1 protein expression of the two strains of ZIKV (MR766 and PE243) in placental explants and cell lines. Thus, PFSE has a promising potential for developing anti-ZIKV treatments, protecting the placenta against infection caused by ZIKV, along with relevant antioxidant potential, represented by ferric reducing antioxidant power (FRAP) of 390.5 Trolox eq per $\mathrm{g}$ dry extract and half maximal inhibitory concentration $\left(\mathrm{IC}_{50}\right)$ for 2,2-diphenyl-1-picrylhydrazyl radical (DPPH') of $12.1 \mu \mathrm{g} \mathrm{mL}^{-1}$, and more than $90 \%$ protection from lipid peroxidation. Although further studies need to be conducted, PFSE treatment was safe and effective in trophoblast cells and placental explants, thus representing a promising class of all-accessible products based on the reuse of industrial by-products.
\end{abstract}

Keywords: passion fruit seeds, placenta protection, antiviral activity, piceatannol, agroindustrial waste

\section{Introduction}

Brazil is the largest producer of yellow passion fruit (Passiflora edulis f. flavicarpa) in the world, with

*e-mail: mofg@qui.ufal.br

\#Jadriane A. Xavier and Jaqueline C. Santos contributed equally to the work.

Editor handled this article: Teodoro S. Kaufman approximately $60 \%$ of the global production. ${ }^{1,2}$ Passion fruit is widely planted in tropical and subtropical regions in several parts of the world, especially in South America, the Caribbean, South Florida, South Africa, and Asia. ${ }^{3}$ Passion fruit has a yellowish peel in maturity, and contains multiple seeds (dark in color) surrounded by yellow gelatinous pulp with an acid-sweet flavor and intense aroma. ${ }^{2}$ The seeds are widely used for the extraction of oil, which serves as raw 
material, mainly for cosmetic and nutritional purposes. ${ }^{4}$ After extracting the oil from the seeds, a residual cake is obtained, which is generally underutilized. However, it is rich in bioactive compounds such as the stilbenes piceatannol and scirpusin B, phenolic compounds and flavonoids. ${ }^{5}$

Beneficial biological activities have been reported for the Passiflora edulis species, from different parts of the plant, ${ }^{3}$ including anti-inflammatory, ${ }^{6}$ neuropharmacological and antidepressant effects, ${ }^{7,8}$ anti-aging, ${ }^{9}$ and antiproliferative effects on cancer cells via glyoxalase I (GLO I), the cellular enzyme that participates in the detoxification of methylglyoxal ${ }^{10}$ these effects also have been observed for its constituents, piceatannol and scirpusin $\mathrm{B},{ }^{10}$ which prevent lipid oxidation in dairy beverages, ${ }^{11}$ have a suppressive effect on $\operatorname{IgE}$ production revealing their antiallergic potential, ${ }^{12}$ attenuate oxidative stress ${ }^{13}$ and have antidiabetic and antiplatelet effects, ${ }^{14}$ among others. To our knowledge, there are still no reports on the protective effect against Zika virus (ZIKV) infection, and dereplication strategies have played a central role in various strategies to define possible new biological activities for natural products. ${ }^{15}$ In this way, the determination of the chemical composition of complex mixtures like ethanol passion fruit seed extract (PFSE) can be a challenge. Mass spectrometry is one of the possible analytical methods for metabolomics analyses in natural products, looking for or not for specific chemical signals. ${ }^{15}$ In a recent study, ${ }^{8}$ the chemical profile of Passiflora edulis leaves, cultivated in the Rio Grande do Norte, was published, where liquid chromatography tandem mass spectrometry (LC-MS/MS) had shown a predominant accumulation of C-flavonoids in this cultivar. All structures were proposed based on the gas phase decomposition chemistry. Later, the injection of standards confirmed all the proposals, ${ }^{8}$ opening the perspective to use the same strategy for seeds extracts analysis.

In recent years, several arboviruses, a high proportion seen in tropical and subtropical regions, have been responsible for numerous outbreaks worldwide. ${ }^{16}$ Among arboviruses, ZIKV has attracted worldwide attention since the appearance of the infection in Brazil in 2015, ${ }^{17}$ where it caused a worrying number of newborns with brain malformations. ${ }^{18} \mathrm{ZIKV}$ infection during pregnancy can also lead to infection of the fetus by vertical transmission, which can result in spontaneous abortion, microcephaly, and other neurological damages, in addition to congenital anomalies collectively addressed as ZIKV congenital syndrome. ${ }^{17,19}$ Therefore, the impact of ZIKV infection on human health reflects devastating fetal and neonatal outcomes, including long-term infection. ${ }^{20}$ In this context, preventing placental infection by ZIKV is important in order to protect the fetus; however, existing antiviral drugs may be harmful to the pregnancy.

As such, natural products such as the presently reported PFSE could be an alternative to protect fetuses from the harmful effects of ZIKV infection during pregnancy, which is cited by the World Health Organization (WHO) as a priority in the research and development plans for neglected diseases. ${ }^{21}$

\section{Experimental}

\section{Chemicals}

The analytical grade compounds were purchased from Sigma-Aldrich (Steinheim, Germany): DPPH $(\alpha, \alpha$-diphenylpicrylhydrazyl radical), TPTZ (2,4,6-tripyridyl-s-triazine), AAPH (2,2-azobis(2-amidinopropane)di-hydrochloride), soy phosphatidylcholine, Trolox ${ }^{\circledR}$, methylglyoxal, hemoglobin, fluorescein, formic acid and acetonitrile, F12 culture medium, L-15 medium. Hank's balanced salt solution (HBSS), phosphate-buffered saline (PBS) and trypsin-ethylenediamine tetraacetic acid (EDTA), fetal bovine serum (FBS) and $L$-glutamine were purchased from Thermo Fisher Scientific (Waltham, MA, USA). Chloroquine was provided by Farmanguinhos (Fundação Oswaldo Cruz, Rio de Janeiro, Brazil). 4,4-Difluoro5-(4-phenyl-1,3-butadienyl)-4-bora-3a,4a-diaza- $S$-indacene3-undecanoic acid (C11-BODIPY581/591) was obtained from Molecular Probes (Ontario, Canada). All reagents were of analytical grade, and the stock solutions and buffers were prepared with Milli-Q purified water.

\section{Preparation of the ethanol extracts of passion fruit seeds}

Passiflora edulis seeds were separated from the pulp, washed with distilled water, and dried in an oven at $50{ }^{\circ} \mathrm{C}$ for $48 \mathrm{~h}$. The seeds were then ground in a blade mill and stored in amber glass vials. Firstly, $12 \mathrm{~g}$ of dry seeds was weighed and degreased using hexane $(250 \mathrm{~mL})$ in a Soxhlet apparatus for a period of $6 \mathrm{~h}$ and extraction performed in ethanol $(250 \mathrm{~mL})$ for $6 \mathrm{~h}$. The extract was concentrated in a rotary evaporator, stored in amber glass under refrigeration at $4{ }^{\circ} \mathrm{C}$, and identified as PFSE. SisGen access number: A9493F8.

\section{Characterization of the ethanolic extract}

The PFSE was analyzed by high-performance liquid chromatography (HPLC) with a diode array detector coupled to a mass spectrometer with electrospray ionization source (ESI) and time of flight analyzer (HPLC-ESI-MS/MS, micrOTOF-QII, Bruker Daltonics ${ }^{\circledast}$, Billerica, MA, USA). 
For chromatographic analysis, $5 \mathrm{mg}$ of the PFSE was mixed with $2 \mathrm{~mL}$ of a methanol-water solution (75:25). The chromatographic parameters used were: Kinetex XB C18 column $(100 \times 2.1 \mathrm{~mm}, 2.6 \mu \mathrm{m}, 100 \AA)$, temperature $40{ }^{\circ} \mathrm{C}$, injection volume $2 \mu \mathrm{L}$, and flow rate $0.4 \mathrm{~mL} \mathrm{~min}^{-1}$. The mobile phase was composed of $0.1 \%$ formic acid in water (v/v; solvent A) and $0.1 \%$ formic acid in acetonitrile (v/v; solvent B). The elution gradient started with a ramp 5 to $35 \% \mathrm{~B}$ for $23 \mathrm{~min}, 35$ to $100 \% \mathrm{~B}$ for $17 \mathrm{~min}$, maintaining $100 \% \mathrm{~B}$ for $8 \mathrm{~min}$ and then 100 to $5 \% \mathrm{~B}$ in $2 \mathrm{~min}$, remaining at $5 \% \mathrm{~B}$ for $10 \mathrm{~min}$ and ending the run in a total time of $60 \mathrm{~min}$.

The detection system consisted of a mass spectrometer operated in positive and negative ionization modes. In the first ionization mode, a capillary voltage of $4.5 \mathrm{kV}$ and a cone voltage of $500 \mathrm{~V}$ were used as instrumental parameters. For the negative ionization mode, a capillary voltage of $3.2 \mathrm{kV}$ and a cone voltage of $400 \mathrm{~V}$ were used. In both measurement modes, a temperature of $200{ }^{\circ} \mathrm{C}$ and a mass detection range of $m / z, 50-1500$ were used. The parameters of MS/MS were Auto MS/MS with the selection of precursor ions in cycles of $3.0 \mathrm{~s}$, excluding the selection after detection of two spectra of the same ion or after $0.60 \mathrm{~min}$, reconsidering its selection if the ion intensity precursor was twice the previous. For the fragmentation of precursor ions a collision energy ramp of 20 to $50 \mathrm{eV}$ was used.

\section{Radical scavenging ability toward $\mathrm{DPPH}^{\bullet}\left(\mathrm{RSA}-\mathrm{DPPH}^{\circ}\right)$}

The antioxidant capacity of the PFSE was determined by radical scavenging using the $\mathrm{DPPH}^{\cdot}$ method. ${ }^{22}$ Aliquots of $0.30 \mathrm{~mL}$ of the extract dissolved in ethanol $\left(5-25 \mu \mathrm{g} \mathrm{mL}^{-1}\right)$ were mixed with $2.70 \mathrm{~mL}$ of $\mathrm{DPPH}^{\bullet}$ solution $\left(40 \mu \mathrm{g} \mathrm{mL}^{-1}\right.$ in methanol). The mixture was then homogenized and stored in the dark for $30 \mathrm{~min}$ and the measurements performed at $516 \mathrm{~nm}$, using a UV-Vis spectrophotometer (Agilent 8453, Burlington, MA, United States). The analyses were performed in triplicate $(n=3)$ and the percentage inhibition or the $\mathrm{IC}_{50}$ (half maximal inhibitory concentration) was calculated graphically, using an analytical curve in the linear range, by plotting the extract concentration versus the corresponding scavenging effect (I\%, inhibition percentage) at $30 \mathrm{~min}$.

\section{Ferric reducing antioxidant power (FRAP) assay}

The FRAP assay was performed according to the method described previously with some modifications. ${ }^{23}$ Briefly, the FRAP reagent was prepared by mixing a solution of TPTZ $(10 \mathrm{mM})$ in $40 \mathrm{mM} \mathrm{HCl}, \mathrm{FeCl}_{3}(20 \mathrm{mM})$, and acetate buffer ( $\mathrm{pH} 3.6,0.30 \mathrm{M}) .90 \mu \mathrm{L}$ of sample
( $25 \mu \mathrm{g} \mathrm{mL}^{-1}$ ) were mixed with $2.7 \mathrm{~mL}$ of FRAP reagent and then incubated at $37{ }^{\circ} \mathrm{C}$ for $30 \mathrm{~min}$. The absorbance of the reaction mixture was measured at $595 \mathrm{~nm}$ and an analytical curve prepared with Trolox ${ }^{\circledR}\left(0.04\right.$ to $\left.7.50 \mu \mathrm{g} \mathrm{mL}^{-1}\right)$. The analyses were performed in triplicate $(n=3)$ and the results expressed as Trolox equivalent antioxidant capacities (TEAC) in mg Trolox eq per $\mathrm{g}$ dry extract.

\section{Lipid peroxidation measurements}

Unilamellar vesicles of soy phosphatidylcholine $(1 \mathrm{mM})$ were prepared by extrusion $(100 \mathrm{~nm}$ pore diameter membrane, at $\left.25{ }^{\circ} \mathrm{C}\right),{ }^{24}$ in $10 \mathrm{~mL}$ of phosphate buffer $(50 \mathrm{mM})$ at $\mathrm{pH} 7.4$ with the additional incorporation of $0.1 \mu \mathrm{M}$ of the peroxyl-sensitive fluorescent probe C11-BODIPY581/591. ${ }^{25}$ The particle size was measured by Nanotrac-Zetatrac, model NPA151-31 A-0000-D30-10 M (Microtrac, Burlington, MA, United States), at around $100 \mathrm{~nm}$.

Fluorescence measurements were carried out at $37^{\circ} \mathrm{C}$, using an RF-5301PC spectrofluorophotometer (Shimadzu, Minato, Japan). In a 1-mL quartz cuvette, adequate amounts of unilamellar vesicle suspension, phosphate buffer $\mathrm{pH}$ 7.4, and the PFSE $\left(5,25\right.$, and $\left.50 \mu \mathrm{g} \mathrm{mL}^{-1}\right)$ or positive control (Trolox, $100 \mu \mathrm{g} \mathrm{mL}^{-1}$ ) were mixed. Ethanol was used as negative controls. The reaction was initiated by the addition of $100 \mu \mathrm{L}$ of AAPH $(100 \mathrm{mM})$. The fluorescence decay of fluorescent probe $\left(\lambda_{\mathrm{ex}}=580 \mathrm{~nm}, \lambda_{\mathrm{em}}=600 \mathrm{~nm}\right)$ was monitored continuously for $30 \mathrm{~min}$. The analyses were performed in triplicate $(n=3)$.

\section{HTR-8/SVneo cell line culture}

The HTR-8/SVneo (ATCC ${ }^{\circledR}$ CRL-3271 ${ }^{\mathrm{TM}}$ ) was kindly donated by Prof Estela Bevilacqua from the University of São Paulo. It was a placental cell line derived from first-trimester extravillous trophoblast cells, routinely cultured in DMEM/F12 medium, supplemented with $10 \%$ (v/v) FBS and $2 \mathrm{mM} L$-glutamine and kept in a humid incubator at $37{ }^{\circ} \mathrm{C}$ and $5 \% \mathrm{CO}_{2}$. Cells were subcultured every 5 days with $80 \%$ confluence for HTR-8/SVneo cells and the medium replenished every 2 days.

\section{Ethical issues}

The ethical committee approved the use of placentas from the Federal University of Alagoas through the national Plataforma Brasil unified system (CAEE 57828616.3.0000.5013), with signed informed consent from all patients according to Brazilian Health Ministry guidelines. 
Placenta collection and chorionic villi explant culture

Placentas derived from term pregnancies (37-40 weeks of pregnancy) were obtained from the Obstetrics Service of Prof Alberto Antunes University Hospital of the Federal University of Alagoas, Brazil (HUPAA/UFAL) by elective cesarean section. Five-term placentas from healthy pregnant women were collected from women with no detectable infections, hypertensive disorders, chronic diseases, or other conditions. After placenta collection, fresh samples from the chorionic villi were washed extensively in 0.1 M PBS and HBSS, followed by the separation of terminal chorionic villi for explant culture in 24-well plates with DMEM/F12-supplemented medium, and kept in a humid incubator at $37{ }^{\circ} \mathrm{C}$ and $5 \% \mathrm{CO}_{2}$ where they could be cultured for 12 days without losing significant viability, as described previously, ${ }^{26}$ and used routinely worldwide.

The 3-(4,5-dimethylthiazol-2-yl)-2,5-diphenyltetrazolium bromide (MTT) cell viability assay

The MTT assay was used to verify the possible cytotoxicity of the PFSE on both placental cell lines and placental explant cultures. As such, placental explants were weighed and plated in equal proportions in each well, and Vero E6 cells or HTR-8/SVneo cells were plated at $2.5 \times 10^{5}$ cells per well and treated with the extract diluted in DMEM/F12 medium in different concentrations $(0.01$, $0.1,1,10$, and $\left.100 \mu \mathrm{g} \mathrm{mL}^{-1}\right)$, and cultured for a further $24 \mathrm{~h}$. Since chloroquine (CQ) has been described as a potent in vitro anti-ZIKV agent, ${ }^{27-29}$ we tested whether it would affect cell lines or placental explants viability at $50 \mu \mathrm{g} \mathrm{mL}^{-1}$, in order to use it as a positive control added $1 \mathrm{~h}$ after ZIKV incubation. The control group had no addition of extracts. The medium was replaced with a fresh culture medium containing $5 \mu \mathrm{g} \mathrm{mL}^{-1}$ of MTT and the supernatant discarded after a 4-h incubation period at $37^{\circ} \mathrm{C}$, followed by the addition of $150 \mu \mathrm{L}$ of DMSO. The absorbance of the dissolved MTT formazan product was measured spectrophotometrically at $540 \mathrm{~nm}$. The percentage viability was determined in relation to the controls [(absorbance of treated cells/absorbance of untreated cells $) \times 100]$.

\section{Zika virus propagation and titration}

Two stock strains of ZIKV were kindly donated by Dr Juliano Bordignon from the Instituto Carlos Chagas of Fundação Oswaldo Cruz (ICC/FIOCRUZ-PR): the MR766 strain (isolated in Uganda in 1947, third passage, stock titer of $6.25 \times 10^{7}$ fluorescent focus units (FFU) $\mathrm{mL}^{-1}$, GenBank accession KX421193), and the PE243 strain (isolated in Pernambuco, Brazil in 2016, third passage, stock titulation of $1 \times 10^{8} \mathrm{FFU} \mathrm{mL} \mathrm{mL}^{-1}$, GenBank accession MF352141.1). To perform viral propagation, both strains were cultured, in separate, in Aedes albopictus derived C6/36 cells with L-15 medium supplemented with $10 \%$ (v/v) FBS, $10 \%$ (v/v) tryptose and 1\% PSA until $80 \%$ confluence. Cellfree supernatants were harvested 5 days post-infection (dpi), aliquoted, and stored at $-80{ }^{\circ} \mathrm{C}$. Titration was performed after viral infection using green monkey kidney-derived Vero E6 cells cultured with supplemented DMEM for $1 \mathrm{~h}$ under gentle agitation. The media was changed and cells were incubated with $1.5 \%(\mathrm{~m} / \mathrm{v})$ carboxymethylcellulose (CMC) in DMEM with 2\% FBS at 1:1 (v/v). Plaque formation was observed at 5 dpi after $10 \%(\mathrm{v} / \mathrm{v})$ formalin fixation and $2 \%(\mathrm{v} / \mathrm{v})$ violet crystal staining. Viral titration of MR766 strain was stocked at $5 \times 10^{5}$ plaque-forming units $(\mathrm{PFU}) \mathrm{mL}^{-1}$ and PE243 at $3 \times 10^{5} \mathrm{PFU} \mathrm{mL}^{-1}$.

\section{ZIKV infection of HTR-8/SVneo cells and treatment}

Cells were plated at $3 \times 10^{5}$ cells per well in 24-well plates for $24 \mathrm{~h}$, with DMEM/F12 medium supplemented with $2 \%$ FBS and received $100 \mu \mathrm{g} \mathrm{mL}^{-1}$ of the PFSE for $1 \mathrm{~h}$. Afterward, cells were infected with one multiplicity of infection (MOI) of MR766 or PE243 ZIKV strains for $1 \mathrm{~h}$. The supernatant was removed and the cells washed thoroughly with PBS. A new culture medium was added and the cells cultured for $24 \mathrm{~h}$. Positive controls were performed with addition of $100 \mu \mathrm{g} \mathrm{mL}^{-1}$ of chloroquine diphosphate to the cultures after ZIKV incubation and culture medium change. As such, cultures after the medium change were nominated as $0 \mathrm{~h}$ and all time-points afterward showed only the effects derived from the $1-\mathrm{h}$ ZIKV incubation. The ZIKV infection efficiency was accessed by flow cytometry, quantitative reverse transcription polymerase chain reaction (RT-qPCR) and immunofluorescence. ${ }^{30}$

\section{Flow cytometry analysis of ZIKV infection}

To access the percentage of cells infected by ZIKV, cells were detached with $2.5 \%$ trypsin-EDTA, and fixation and permeabilization were performed using commercial flow cytometry kits (e-Bioscience, San Diego, CA, USA). A monoclonal primary mouse antibody anti-ZIKV NS1 (1:100, E107, MA5-24585, Invitrogen, Carlsbad, CA, USA) was incubated with Zenon Alexa 488-conjugated secondary anti-mouse antibody (1:250; Thermo Fisher Scientific Burlington, MA, USA) for $5 \mathrm{~min}$ to form an immunocomplex with further addition of Zenon Blocking 
Reagent for further $5 \mathrm{~min}$. The immunocomplex was later incubated with cells for $1 \mathrm{~h}$ at $37{ }^{\circ} \mathrm{C}$. The percentage of ZIKV infected cells was analyzed with FACS CantoTM ${ }^{\circledR}$ II flow cytometer (BD Biosciences, San Jose, CA, USA), using FlowJo software (BD Biosciences).

\section{Quantitative reverse transcription polymerase chain reaction} (RT-qPCR)

The ribonucleic acid (RNA) viral load from the cellular supernatants was extracted using PureLink ${ }^{\mathrm{TM}}$ Viral RNA/ DNA Mini Kit (Invitrogen, Carlsbad, CA, USA), following the manufacturer's instructions. The complementary DNA was synthesized and amplified using M-MLV reverse transcriptase (Invitrogen, Carlsbad, CA, USA). Next, ZIKV RNA copies were quantified using StepOnePlus ${ }^{\mathrm{TM}}$ RealTime PCR System (Applied Biosystems, Life Technologies, Foster City, CA, USA). For each single-well amplification reaction, a threshold cycle $(\mathrm{Ct})$ was evaluated in the exponential phase. The primers used were ZIKV 1086 and ZIKV 1162c. ${ }^{31}$

\section{Immunofluorescence for ZIKV NS1}

The HTR-8/SVneo cells were fixed with $4 \%(\mathrm{v} / \mathrm{v})$ paraformaldehyde in PBS and permeabilized with $0.1 \%$ Triton X-100 in PBS (v/v). Then, unspecific antigens blockade was performed with $0.05 \%$ fish-skin gelatin in PBS (m/v) (Merck/Sigma-Aldrich, Burlington, MA, USA) for $1 \mathrm{~h}$, followed by monoclonal primary mouse antibody anti-ZIKV NS1 (1:100, E107, MA5-24585, Invitrogen, Carlsbad, CA, USA) incubation with Zenon Alexa 488 conjugated secondary anti-mouse antibody (1:250; Thermo Fisher Scientific, Waltham, MA, USA) for $5 \mathrm{~min}$ to form an immunocomplex, which was later incubated with Zenon Blocking Reagent (1:250; Thermo Fisher Scientific, Waltham, MA, USA) for a further $5 \mathrm{~min}$ at room temperature. The immunocomplex mixture was added to cells for $1 \mathrm{~h}$ at $37^{\circ} \mathrm{C}$. Nuclei were stained with 4',6-diamidino-2-phenylindole (DAPI; 1:1000 in PBS; Merck/Sigma-Aldrich, Burlington, MA, USA), and mounting was performed with PBS/glycerol $(1: 9, \mathrm{v} / \mathrm{v})$ under glass slides. The results were visualized with a fluorescence microscope (Nikon DS-Ri1, Minato, Japan) and images acquired using DP2-BSW software (Nikon).

\section{Statistical analyses}

The results for the antioxidant tests were expressed as mean \pm standard deviation $(\mathrm{SD})$, and statistical evaluation was determined by analysis of variance (ANOVA) followed by Tukey's post-test. The results for the antiviral tests were expressed as mean \pm standard error of the mean (SEM), and the statistical evaluation was determined by ANOVA with Geisser-Greenhouse correction followed by Tukey's post-test, at the level of significance of $95 \%$, using Graphpad Prism 8.3.0 software. ${ }^{32}$

\section{Results and Discussion}

\section{Characterization of the ethanol extract}

Initially, the yield of PFSE was $7.9 \%$, calculated from the initial mass of seeds submitted to extraction with ethanol. HPLC-MS/MS analysis of the ethanolic extract was conducted to characterize the major secondary metabolites. The compounds' annotation was supported by the fragmentation profile, ${ }^{33}$ and individual analysis of the gas phase decomposition reactions. ${ }^{34}$ Finally, spectroscopic data and literature comparison were used to support the proposals (Table 1). The dereplication strategies allowed the annotation of 10 compounds in total, of which five were identified in negative ionization mode and five in positive ionization mode. The detailed mass spectrometric analyses of the compounds are summarized in the Supplementary Information (SI) section (Figures S1-S12). The results obtained by LC-MS/MS in a negative ionization allowed us to annotate the signals at 18.5, 17.4, 21.0, 22.4, and $17.2 \mathrm{~min}$, referring to [M $-\mathrm{H}]^{-}$ions of $\mathrm{m} / \mathrm{z} 243,405,485$, 469 and 449, respectively, and presented a fragmentation profile consistent with the compounds piceatannol $(\mathrm{m} / \mathrm{z}, 243)$, astringin $(\mathrm{m} / \mathrm{z}, 405)$, scirpusin B $(\mathrm{m} / \mathrm{z} 485)$ and scirpusin A $(\mathrm{m} / \mathrm{z} 469)$ (Figure S11), along with isookanin7-O-glucoside $(\mathrm{m} / \mathrm{z} 449) .{ }^{35-37}$ In the positive ionization mode, it was possible to observe the presence of naringenin7- $O$-glucoside $(\mathrm{m} / \mathrm{z} 435)$, tyrosine $(\mathrm{m} / \mathrm{z} 182)$, phenylalanine $(\mathrm{m} / \mathrm{z}$ 166), and two derivatives of quadranguloside saponin $(\mathrm{m} / z 621$ and $\mathrm{m} / \mathrm{z}$ 593; Figure S12). The absence of signals of C-flavonoids observed confirmed a significant difference of the chemical profiles of leaves and seeds. High resolution analysis, listed in Table 1, confirmed all molecular formulas with less than $10 \mathrm{ppm}$ error, corroborating the correct number of $\mathrm{C}, \mathrm{H}$ and $\mathrm{O}$ atoms.

To reinforce, all mass spectrometric annotations are based on high resolution and fragmentation patterns. As already described in the literature, stilbenes are found in passion fruit seeds. ${ }^{5,10,37-39}$ Astringin is the glycosylated piceatannol molecule; the compounds scirpusin B and scirpusin A are dimers of piceatannol. Of these compounds, piceatannol is the most studied and has shown important biological activities, with antidiabetic, ${ }^{40,41}$ antioxidant, ${ }^{42-44}$ anticancer ${ }^{45,46}$ and anti-inflammatory ${ }^{10,47}$ potential. 
Table 1. Compounds annotated in PFSE by HPLC-DAD-ESI-MS/MS in negative and positive ion modes<smiles>COOc1c(O)cc2c(c1O)OC(c1ccc(O)c(O)c1)CC2=O</smiles>

Astringin<smiles>OCC1OC(Oc2cc(O)cc(/C=C/c3ccc(O)c(O)c3)c2)C(O)C(O)C1O</smiles>

Piceatannol<smiles>Oc1cc(O)cc(/C=C/c2ccc(O)c(O)c2)c1</smiles>

$[\mathrm{M}-\mathrm{H}]^{-}$
$(\mathrm{m} / \mathrm{z})$

17.2

17.4 $217 ; 285 ; 320$

405.1165

$[\mathrm{M}-\mathrm{H}]$
$(\mathrm{m} / \mathrm{z})$

MS/MS fragments $(\mathrm{m} / \mathrm{z})$

Error / ppm

Scirpusin B<smiles>Oc1cc(O)cc(C2c3c(/C=C/c4ccc(O)c(O)c4)cc(O)cc3OC2c2ccc(O)c(O)c2)c1</smiles>

Scirpusin A<smiles>Oc1ccc(C=Cc2cc(O)cc3c2C(c2ccc(O)cc2)C(c2ccc(O)c(O)c2)O3)cc1</smiles>

Naringenin-7-O-glucoside<smiles>O=C1CC(c2ccc(O)cc2)Oc2cc(OC3OC(CO)C(O)C(O)C3O)cc(O)c21</smiles>

$$
\text { P }
$$<smiles>CCC(O)CO</smiles>

Derivative II of quadranguloside<smiles>C/C(=C\CCC1CCC2C3CCC4C(CCC(O)C4(C)C)C34CCC3(C)C(CO)CCC1C23C4)OC1OC(CO)C(O)C(O)C1O</smiles> 
Table 1. Compounds annotated in PFSE by HPLC-DAD-ESI-MS/MS in negative and positive ion modes (cont.)

\begin{tabular}{|c|c|c|c|c|c|c|}
\hline Compound & $t_{R} / \min$ & $\mathrm{UV} / \mathrm{nm}$ & $\begin{array}{c}{[\mathrm{M}-\mathrm{H}]^{-}} \\
(\mathrm{m} / \mathrm{z})\end{array}$ & $\begin{array}{c}{[\mathrm{M}-\mathrm{H}]^{+}} \\
(\mathrm{m} / \mathrm{z})\end{array}$ & $\begin{array}{c}\text { MS/MS } \\
\text { fragments }(m / z)\end{array}$ & Error / ppm \\
\hline \multicolumn{7}{|l|}{ Tyrosine } \\
\hline & 0.9 & $255 ; 334$ & - & 182.0847 & $\begin{array}{c}20-50 \mathrm{eV}: \\
182 \rightarrow 136 ; 123\end{array}$ & \\
\hline \multicolumn{7}{|c|}{ Phenylalanine } \\
\hline & 1.6 & $218 ; 266$ & - & 166.0869 & $\begin{array}{c}20-50 \mathrm{eV}: \\
166 \rightarrow 120 \\
103 ; 91\end{array}$ & \\
\hline
\end{tabular}

Scirpusins A and B showed in vitro anti-HIV-1 ${ }^{48}$ (IIIB strain) activity. Sano et al. ${ }^{37}$ isolated piceatannol and scirpusin B from passion fruit seeds and demonstrated their antioxidant and vasorelaxing potential, ${ }^{37}$ with scirpusin B showing better effects than piceatannol. Scirpusin B also showed hypoglycemic activity through an amylase inhibitory activity ${ }^{39}$ Scirpusin A showed strong inhibition of the $\beta$-amyloid peptide aggregation process, ${ }^{49}$ and inhibitory activity of arginase in mammals. ${ }^{50}$

Isoflavonoids like naringenin can be found mainly in citrus fruits, ${ }^{51}$ and soybeans cultivars. ${ }^{52}$ Narigenin has several biological properties, such as attenuation of oxidative stress, and regulation of Nrf2 and its target genes, ${ }^{53}$ and levels of reduced glutathione (GSH) in cells, ${ }^{54}$ acting in the prevention of non-alcoholic fatty liver disease,,$^{55}$ attenuating renal interstitial fibrosis and the expression of inflammatory factors,$^{56}$ and improving steatohepatitis induced by type 2 diabetes mellitus, ${ }^{57}$ among others. Flavonoids such as isookanin, with a catechol moiety, have one important structural requirement to inhibit the neutrophil superoxide anion generation, ${ }^{58}$ and demonstrate anti-inflammatory, ${ }^{59}$ and antidiabetic ${ }^{60}$ activities.

Saponins are used as vaccine adjuvants. Cibulski et al. ${ }^{61}$ used a saponin-rich fraction of the Quillaja brasiliensis species and a nanoadjuvant with this fraction in experimental vaccines against ZIKV and observed stimulation of the immune response. ${ }^{61}$ The presence of saponins in the Passiflora genus has been previously described. ${ }^{62,63}$

In this work, through the fragmentation profile of the saponin quadranguloside, we found two possible derivatives. The derivative I $(\mathrm{m} / \mathrm{z}, 621)$ refers to the quadranguloside with one less gentiobiose moiety, and linked to a glucose molecule. According to Reginatto et al. ${ }^{64}$ the quadranguloside $\mathrm{C}_{34} \mathrm{H}_{56} \mathrm{O}_{8}$ is known as 9,19-cyclolanost24-Z-en-3b,21,26-trihydroxy-3,26-di-O-gentiobiose. ${ }^{64} \mathrm{This}$ generates the derivative II $(\mathrm{m} / \mathrm{z}, 593)$, through the loss of one of the gentibiose groups and one glucose molecule (Figure S13, SI section). In both cases we are able only to characterize the signals by mass spectrometry, but our data open the perspective for an isolation guide by MS to characterize these metabolites and possible new analogues, as described in several metabolomics protocols. ${ }^{15,52}$

\section{In vitro radical scavenging assays}

Oxidative stress is directly related to numerous diseases, including those caused by viral infections, promoting virus replication in infected cells, decreasing cell proliferation and inducing cell apoptosis. ${ }^{65}$ Almeida et al.${ }^{66}$ investigated the role of oxidative stress in ZIKV infection and observed in infected cells a significant increase in ROS production, in the formation of lipid peroxidation products, in carbonyl protein levels, in addition to a decrease in the activities of the redox enzymes superoxide dismutase and catalase. In this context, the antioxidant potential was investigated using the methods of DPPH', FRAP and lipid peroxidation.

PFSE exhibited an $\operatorname{IC}_{50}$ (DPPH) value of $12.1 \pm 1.6 \mu \mathrm{g} \mathrm{mL}^{-1}$ and $390 \pm 6 \mathrm{mg}$ Trolox eq per $\mathrm{g}$ dry extract in the FRAP analysis. Yepes et al. ${ }^{9}$ studied the ethanolic extract of purple passion fruit seeds and found an $\mathrm{IC}_{50}(\mathrm{DPPH})$ value of $132.6 \mu \mathrm{g} \mathrm{mL} \mathrm{L}^{-1}$, about 10-fold higher than the present study. Rotta et al. ${ }^{11}$ obtained an $\mathrm{IC}_{50}(\mathrm{DPPH})$ of $19 \pm 3 \mu \mathrm{g} \mathrm{mL}^{-1}$ for the Passiflora edulis seed extract, similar to the present study.

The lipid peroxidation inhibition assay was also performed to evaluate the antioxidant potential of the PFSE; the effects against lipid peroxidation at concentrations of 5, 25 and $50 \mu \mathrm{g} \mathrm{mL}^{-1}$ are shown in Figure 1. The experiments with the blank (ethanol) in the absence of antioxidants showed that the liposomal lipid peroxidation induced by AAPH occurs, causing the loss of fluorescence. The positive control, Trolox ${ }^{\circledR}\left(100 \mu \mathrm{g} \mathrm{mL}^{-1}\right)$, inhibited lipid peroxidation 
and offered approximately $95 \%$ protection at the end of the

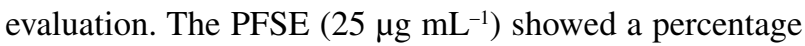
inhibition of lipid peroxidation similar to that of Trolox ${ }^{\circledR}$.

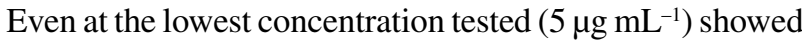
protection within $10 \mathrm{~min}$, similar to that found for the other concentrations and at the end of $30 \mathrm{~min}$ monitoring, about $70 \%$ inhibition. de Oliveira et al ${ }^{67}$ studied the methanolic extract of passion fruit residue and observed a protection against lipid peroxidation higher than $90 \%$, similar to that found in this study.

The PFSE showed significant protection against lipid peroxidation, further highlighting the promising potential of this extract in inhibiting or delaying oxidative damage.

\section{Analyses of aqueous extracts in Vero E6 and HTR-8/SVneo} cells and placental explant viability

The PFSE was first dissolved in an aqueous solution and analyzed in the Vero E6 cell line. As a result, no decrease whatsoever in cell viability was observed, and at the highest concentration used $\left(100 \mu \mathrm{g} \mathrm{mL}^{-1}\right)$ a solid increase in viability was seen, which might be related to a possible increase in proliferation or mitochondrial activity (Figure $2 \mathrm{a}$ ). Then, we

(a)

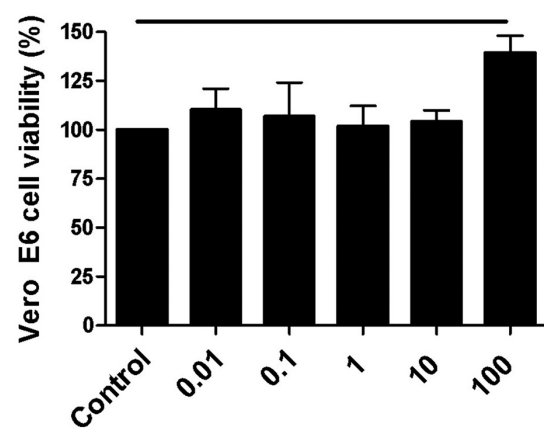

PFSE Treatment $\left(\mu \mathrm{g} \mathrm{mL}^{-1}\right)$

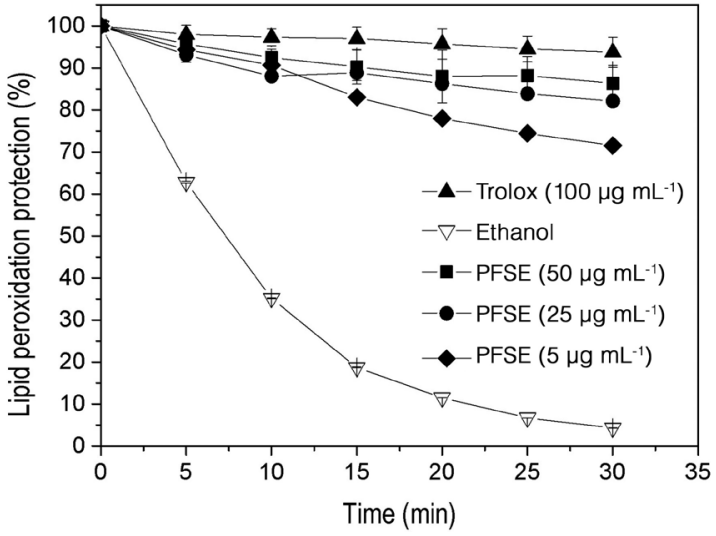

Figure 1. Potential inhibitor of lipid peroxidation of passion fruit seed extract (PFSE) in different concentrations $\left(5,25\right.$, and $\left.50 \mu \mathrm{g} \mathrm{mL}^{-1}\right)$ during the 30 min time interval.

tested cell viability of placental human HTR-8/SVneo cells in the presence of PFSE, also with no reduction in cell viability at any concentration used (Figure $2 b$ ). We further analyzed the PFSE toxicity on human placental tissue explant culture, and no reduction on placenta viability was observed at all the various concentrations analyzed (Figure 2c), indicating that the extract is well tolerated by cell lines and human placental tissue explants.

(b)

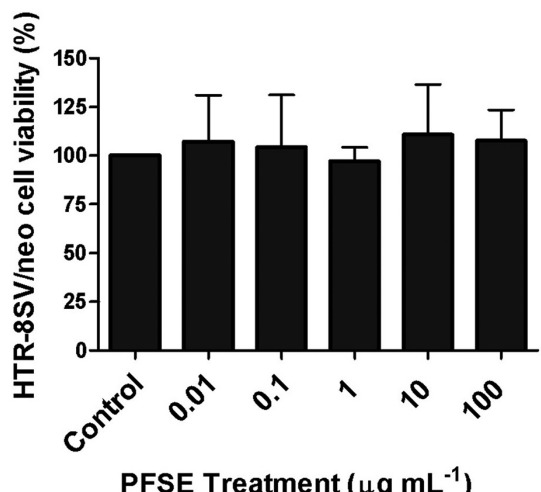

(c)

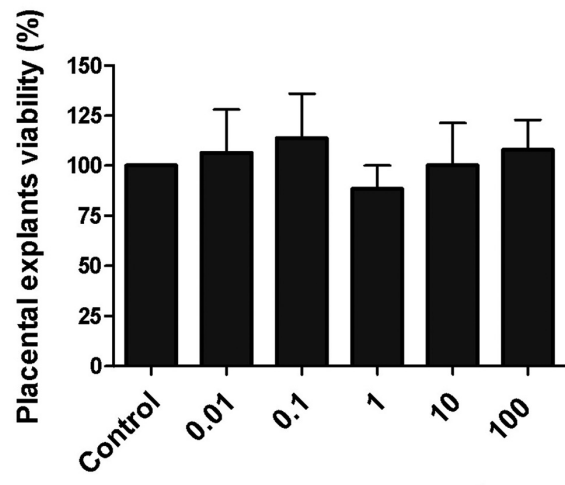

PFSE Treatment $\left(\mu \mathrm{g} \mathrm{mL}^{-1}\right)$

Figure 2. Cellular viability in Vero E6 cells (a), HTR-8/SVneo cells (b) and placental tissue explants viability (c) under different concentrations of passion fruit seed extracts (PFSE). Cells and explants were treated with DMEM/F12 solution (control), with $0.01,0.1,1,10$, and $100 \mu \mathrm{g} \mathrm{mL}{ }^{-1} \mathrm{PFSE}$. The bar graphs represent the mean values $\pm \mathrm{SEM} ; \mathrm{n}=3, * p<0.05$. 
Viral load RT-qPCR analysis from HTR-8/SVneo cells treated with PFSE and infected with ZIKV

HTR-8/SVneo cells were plated at $1 \times 10^{6}$ cells per well and treated, as described above, with $1 \mathrm{~h}$ of ZIKV incubation, culture medium removal and PBS washing with the addition of fresh medium. The supernatants were collected and analyzed by RT-qPCR to evaluate the concentration of eventual new viral copies released by infected cells. After $24 \mathrm{~h}$, cells infected with the MR766 strain showed an average viral load of $4.772 \pm 1.148 \times 10^{4} \mathrm{PFU} \mu \mathrm{L}^{-1}$, and both treatments, with $1 \mathrm{~h}$ or $24 \mathrm{~h}$ of PFSE exposure, significantly reduced the viral load to $0.927 \pm 0.047 \times 10^{4} \mathrm{PFU} \mu \mathrm{L}^{-1}$ and $0.649 \pm 0.292 \times 10^{4} \mathrm{PFU} \mu \mathrm{L}^{-1}$, respectively (both with $p<0.01$ in comparison to ZIKV MR766 group; Figure 3a). Moreover, cells infected with the PE243 strain showed an average of $5.956 \pm 2.089 \times 10^{5} \mathrm{PFU} \mu \mathrm{L}^{-1}$, and a remarkable reduction of viral load when the PFSE was added as a treatment for $1 \mathrm{~h}$ and $24 \mathrm{~h}$, which ablated to $0.127 \pm 0.002 \times 10^{5} \mathrm{PFU} \mu \mathrm{L}^{-1}$ and
$0.161 \pm 0.062 \times 10^{5} \mathrm{PFU} \mu \mathrm{L}^{-1}$, respectively $(p<0.05$ and $p<0.01$ in comparison to ZIKV PE243 group; Figure $3 \mathrm{~b}$ ). As such, $1 \mathrm{~h}$ of treatment with PFSE was enough to reduce the viral load from both ZIKV strains consistently, and the effect was the same with $24 \mathrm{~h}$ of treatment.

Regarding the placental explants, they were infected with PE243 ZIKV strain only, once the MR766 strain already was shown to not infect them. ${ }^{30}$ The infected explants had an average of $2.769 \pm 0.896 \times 10^{5} \mathrm{PFU} \mu \mathrm{L}^{-1}$, and a remarkable reduction of viral load when PFSE was added as a treatment for $24 \mathrm{~h}$, which reduced the viral load to $0.041 \pm 0.009 \times 10^{5} \mathrm{PFU} \mu \mathrm{L}^{-1}(p<0.01$ in comparison to ZIKV PE243 group; Figure 3c).

Flow cytometry and immunofluorescence analysis on ZIKV NS1 protein expression in HTR-8/SVneo cells

Since the extract was well tolerated by trophoblast cells and placental tissue explants and reduced ZIKV viral load remarkably for both strains, we aimed to verify

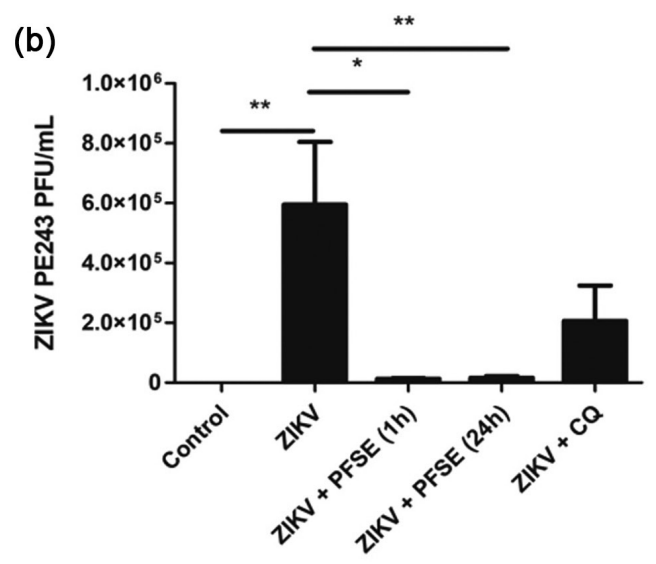

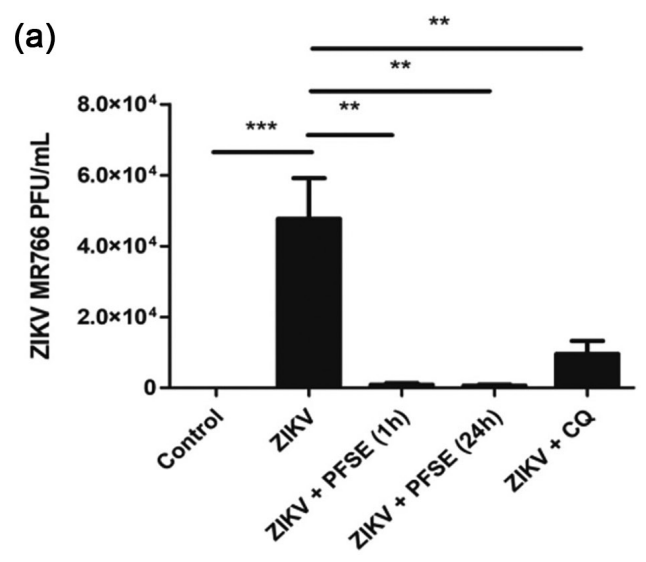

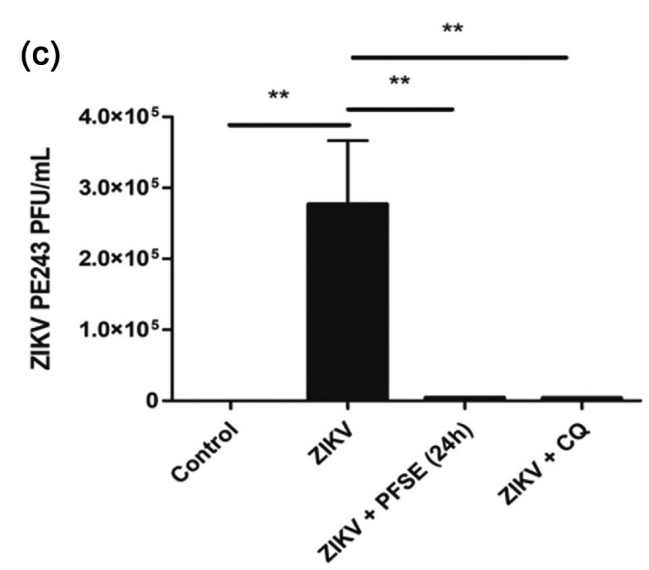

Figure 3. RT-qPCR analyzes of ZIKV viral load after HTR-8/SVneo cells or placental explants infection. After ZIKV MR766 strain (a) or ZIKV PE243 (b) infection in HTR-8/SVneo cells, and ZIKV PE243 (c) infection in placental explants. Treatments were made with DMEM/F12 solution (control), and with $100 \mu \mathrm{g} \mathrm{mL} \mathrm{L}^{-1}$ of passion fruit seed extract (PFSE) $1 \mathrm{~h}$ and $24 \mathrm{~h}$ prior viral incubation, and with $50 \mu \mathrm{g} \mathrm{mL}^{-1}$ of chloroquine (CQ) after $1 \mathrm{~h}$ of viral incubation. After culture medium renewal, cells were left for $24 \mathrm{~h}$, and their supernatants were analyzed to observe ZIKV viral load. The bar graphs represent the mean values $\pm \mathrm{SEM} ; \mathrm{n}=4$ for explants and $\mathrm{n}=5$ for cells. $* p<0.05 ; * *<<0.01 ; * * * p<0.001$. 
(a)

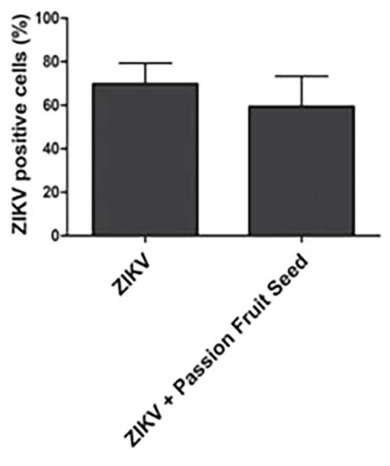

(b)

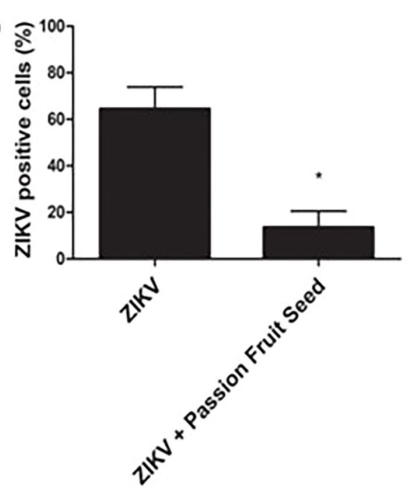

(c)

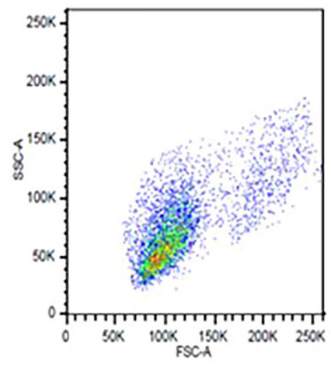

(d)

C-

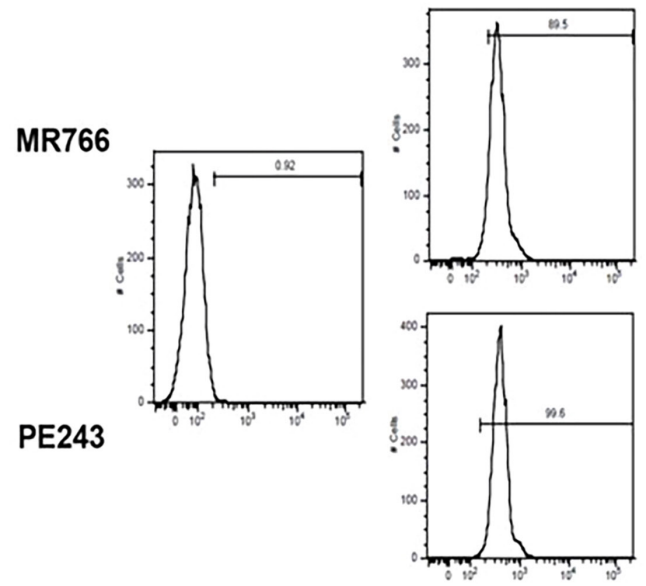

Passion Fruit Seed + ZIKV
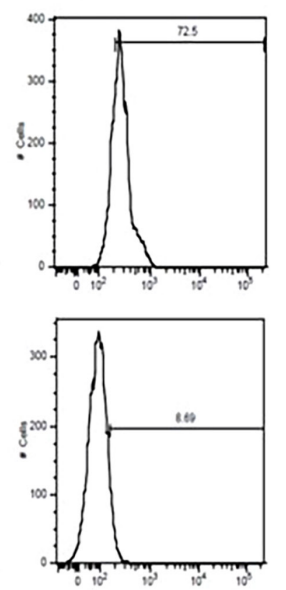

Figure 4. Flow cytometry analysis on passion fruit seed extract treatment on ZIKV placenta infection. HTR-8/SVneo cells were pre-treated with $100 \mu \mathrm{g} \mathrm{mL}{ }^{-1}$ of the extract for $1 \mathrm{~h}$ and further infected with MR766 ( $\mathrm{a}$ and d) or PE243 ( $\mathrm{b}$ and d) ZIKV strains. Cellular gate for size and granularity of HTR-8/SVneo cells is depicted in (c). In (d), negative control (C-), in the first line MR766 and second-line PE243 strain. The treatment was able to reduce remarkably PE243 NS1 protein in trophoblast cells, which indicated reduced infection ( $\mathrm{b}$ and d). Experiments were performed in $\mathrm{n}=3 .{ }^{*} p<0.05$.

ZIKV NS1 protein expression by flow cytometry analysis in HTR-8/SVneo cells. As such, the MR766 strain infected an average of $69.7 \pm 9.68 \%$ of cells in the control group (Figures $4 \mathrm{a}$ and $4 \mathrm{~d}$ ), but the treatment was unable to reduce the number of cells with ZIKV positivity $(59.27 \pm 14.05 \%)$. As such, it seems that cells are infected but viruses are not released into the culture media, since the viral load was reduced after the treatment, as previously shown here. The
PE243 strain infected an average of $64.47 \pm 9.38 \%$ in the control group (Figures $4 \mathrm{~b}$ and $4 \mathrm{~d}$ ), whereas the treatment was able to reduce consistently the ZIKV positivity to $13.55 \pm 6.97 \%(p=0.024)$, indicating that the PFSE was able to reduce both viral load in the culture medium and cellular infectivity of trophoblast cells. Immunofluorescence confirmed the results obtained by flow cytometry, showing that NS1 ZIKV protein was not found in control cells (Figure 5a), (a)

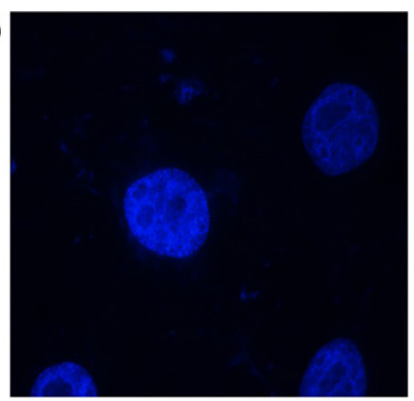

(b)

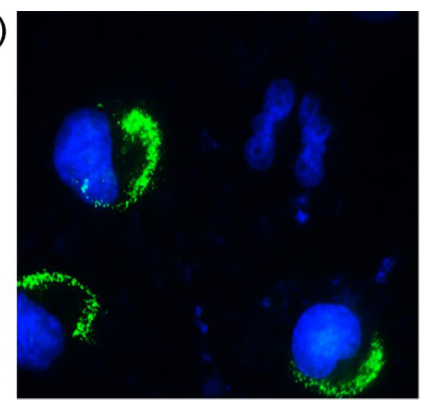

(c)

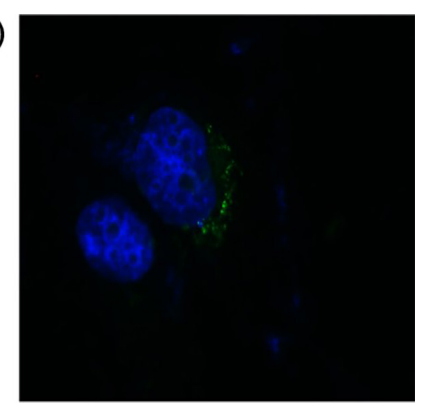

Figure 5. Immunolocalization of ZIKV NS1 in HTR-8/SVneo cells. The ZIKV NS1 (green) was localized in control (a), cells infected with PE243 strain (b) and cells treated with PFSE for $24 \mathrm{~h}$, then infected with ZIKV PE243 (c). Nuclei stained with DAP-I (blue). Cells infected with PE243 strain showed intense staining in the cytoplasm, whereas PFSE treated cells had lower amount and intensity in comparison. Images acquired with $100 \times$ magnification. 
and cells infected with PE243 strain and treated with PFSE showed reduced immunolocalization of NS1 proteins in comparison to the PE243 group (Figures 5b and 5c).

Since the WHO included ZIKV as a priority in the research and development plans for neglected diseases that represent potential global threats, ${ }^{21}$ the world has been seeking new therapies and drugs that could be employed against ZIKV infection. In this context, the inhibition or prevention of ZIKV placental infection would also prevent harmful effects to the developing fetus. Nevertheless, existing drugs with antiviral effects against ZIKV are contraindicated in pregnancy, and only a few new compounds are in phase I or II clinical trials. ${ }^{68}$ As such, natural products are thought to represent potential reservoirs of novel and safe antiviral drugs that could indeed advance the treatment of pregnant women. ${ }^{69}$ Therefore, based on our results, PFSE seems to be a promising candidate to further studies on this behalf. PFSE clearly reduced the viral load in different models using tissue explants and cell cultures, as well as reducing NS1 expression in infected cells, which could indicate that PFSE somehow inhibits the viral entrance and should be further investigated to clarify the potential antiviral mechanism.

In addition to investigating the promise of PFSE, we used the antimalarial chloroquine diphosphate as a positive control of antiviral activity, as has been described by different sources. ${ }^{26-28,70}$

Other active plants have been already described, such as extracts of Schinus terebinthifolius Raddi, which showed similar effects on ZIKV entrance into placental cells, ${ }^{30}$ Doratoxylon apetalum extract inhibited ZIKV infection in leukocytes, ${ }^{71}$ (-)-epigallocatechin gallate (EGCG) inhibited ZIKV entry in Vero E6 cells, ${ }^{72}$ and curcumin and suramin also inhibited ZIKV infection of different cells. ${ }^{73,74}$ Other compounds, such as GSK126, nanchangmycin, obatoclax, pentagalloylglucose, saliphenylhalamide (SaliPhe), and 25-hydroxycholesterol have also been described to inhibit ZIKV endocytosis or entry in different models. ${ }^{75}$ Additionally, of the compounds found in PFSE, it has already been shown that one of them, naringenin-7-O-glucoside, has anti-ZIKV activity in different cell lines and dendritic cells. ${ }^{76}$

\section{Conclusions}

This work reported for the first time an extract of passion fruit seeds with antiviral potential against ZIKV, showing no toxicity in trophoblast cells and in explants of human placenta. The treatment consistently reduced both viral load in the culture medium and cellular NS1 expression of trophoblastic cells. The assembly of biologically active compounds in PFSE is relevant. These results show the promising potential of PFSE as an adjunct therapy in human health, especially maternal and child health, notably against ZIKV. Further studies are required, including in vivo tests to assess better the administration in pregnant women, to identify the constituent or constituents responsible for the antiviral activity and to define the mechanism of action to ensure safe and effective future clinical applications.

PFSE is a safe nutraceutical natural product. The use of natural products, in safe and effective doses, may show significant advantages over synthetic drugs: fewer side effects; lower price, making them accessible to patients from lower-income communities; and with additional advantage of being easily included in the diet, so avoiding the distress associated with drug administration.

The valorization of industrial by-products represents a fundamental strategy for a circular and sustainable bioeconomy, especially in the case of new natural therapeutic approaches.

\section{Supplementary Information}

Supplementary data are available free of charge at http://jbcs.sbq.org.br as PDF file.

\section{Acknowledgments}

The authors gratefully acknowledge the financial support of the Brazilian research funding agencies Conselho Nacional de Desenvolvimento Científico e Tecnológico (CNPq) for financial support (435704/2018-4) and fellowships (NPL, JCCS and MOFG), Coordenação de Aperfeiçoamento de Pessoal de Nível Superior-Brazil (CAPES) - Finance Code 001, CAPES/RENORBIO/ PROAP (23038.011373/2017-31), CAPES/PROCAD, INCT-Bioanalítica (process 465389/2014-7), and FAPEAL (PPSUS/Decit/MS/CNPq/SESAU-AL/FAPEAL No.06/2016:60030 000819/2016). The authors wish to thank Aldy dos Santos and Juliane Pereira da Silva for technical assistance to Dr Alessandra Borges for the donation of Vero E3 cells and C6/36 cells and Dr Ênio Bassi and the IMMUNOREG group for the help with viral growth and titration. We acknowledge Farmanguinhos (Fundação Oswaldo Cruz, Rio de Janeiro, Brazil) for providing chloroquine diphosphate.

\section{Author Contributions}

Jadriane A. Xavier and Jaqueline C. Santos (equal contributions) were responsible for conceptualization, formal analysis, investigation, methodology, data curation, and writing original draft; Monique A. Vila Nova, Camilla M. Gonçalves, Keyla S. N. Pires, Flávia A. R. dos 
Santos, Felipe C. da Silva and Danielle R. Pinho were responsible for formal analysis and investigation; Iara B. Valentim, Júnia H. P. Barbosa, Karen S. C. Borbely, and Norberto P. Lopes were responsible for investigation, methodology and writing review and editing; Alexandre U. Borbely and Marília O. F. Goulart were responsible for conceptualization, supervision, formal analysis, funding acquisition, project administration and writing review and editing.

\section{References}

1. Oliveira, D. A.; Angonese, M.; Ferreira, S. R. S.; Gomes, C. L.; Food Bioprod. Process. 2017, 104, 137.

2. Corrêa, R. C. G.; Peralta, R. M.; Haminiuk, C. W. I.; Maciel, G. M.; Bracht, A.; Ferreira, I. C. F. R.; Trends Food Sci. Technol. 2016, 58, 79 .

3. He, X.; Luan, F.; Yang, Y.; Wang, Z.; Zhao, Z.; Fang, J.; Wang, M.; Zuo, M.; Li, Y.; Front. Pharmacol. 2020, 11, 617; Duarte, I. A. E.; Milenkovic, D.; Borges, T. K.; de Oliveira, L. L.; Costa, A. M.; Food Funct. 2021, 12, 11106; Zeraik, M. L.; Pereira, C. A. M.; Zuin, V. G.; Yariwake, J. H.; Rev. Bras. Farmacogn. 2010, 20, 459; Zeraik, M. L.; Serteyn, D.; Deby-Dupont, G.; Wauters, J.-N.; Tits, M.; Yariwake, J. H.; Angenot, L.; Franck, T.; Food Chem. 2011, 128, 259.

4. Kiefer, J.; Lampe, A. I.; Nicoli, S. F.; Lucarini, M.; Durazzo, A.; Molecules 2019, 24, 3219.

5. Gadioli, I. L.; da Cunha, M. S. B.; de Carvalho, M. V. O.; Costa, A. M.; Pineli, L. L. O.; Crit. Rev. Food Sci. Nutr. 2018, 58, 785; Barbosa Santos, T.; de Araujo, F. P.; Neto, A. F.; de Freitas, S. T.; de Souza Araújo, J.; de Oliveira Vilar, S. B.; Brito Araújo, A. J.; Lima, M. S.; Int. J. Fruit Sci. 2021, 21, 255.

6. Montanher, A. B.; Zucolotto, S. M.; Schenkel, E. P.; Fröde, T. S.; J. Ethnopharmacol. 2007, 109, 281.

7. Sena, L. M.; Zucolotto, S. M.; Reginatto, F. H.; Schenkel, E. P.; de Lima, T. C. M.; Exp. Biol. Med. 2009, 234, 967.

8. Alves, J. S. F.; Silva, A. M. S.; da Silva, R. M.; Tiago, P. R. F.; de Carvalho, T. G.; de Araújo Jr., R. F.; de Azevedo, E. P.; Lopes, N. P.; Ferreira, L. D. S.; Gavioli, E. C.; da Silva-Júnior, A. A.; Zucolotto, S. M.; Pharmaceutics 2020, 12, 383.

9. Yepes, A.; Ochoa-Bautista, D.; Murillo-Arango, W.; QuinteroSaumeth, J.; Bravo, K.; Osorio, E.; Arabian J. Chem. 2021, 14 , 102905.

10. Yamamoto, T.; Sato, A.; Takai, Y.; Yoshimori, A.; Umehara, M.; Ogino, Y.; Inada, M.; Shimada, N.; Nishida, A.; Ichida, R.; Takasawa, R.; Maruki-Uchida, H.; Mori, S.; Sai, M.; Morita, M.; Tanuma, S.-i; Biochem. Biophys. Rep. 2019, 20, 100684.

11. Rotta, E. M.; Giroux, H. J.; Lamothe, S.; Bélanger, D.; Sabik, H.; Visentainer, J. V.; Britten, M.; LWT- Food Sci. Technol. 2020, 123, 109088.

12. Mizusaki, A.; Nishi, K.; Nishiwaki, H.; Ishida, M.; Tamamoto, T.; Sugahara, T.; J. Funct. Foods 2017, 32, 176.
13. Kandandapani, S.; Balaraman, A. K.; Ahamed, H. N.; Chin. J. Nat. Med. 2015, 13, 680.

14. Salles, B. C. C.; Silva, M. A.; Taniguthi, L.; Ferreira, J. N.; Rocha, C. Q.; Vilegas, W.; Dias, P. H.; Pennacchi, P. C.; Duarte, S. M. S.; Rodrigues, M. R.; Brigagão, M. R. P. L.; Paula, F. B. A.; Biol. Pharm. Bull. 2020, 43, 169.

15. Pilon, A. C.; Selegato, D. M.; Fernandes, R. P.; Bueno, P. C. P.; Pinho, D. R.; Carnevale Neto, F.; Freire, R. T.; Castro-Gamboa, I.; Bolzani, V. S.; Lopes, N. P.; Quim. Nova 2020, 43, 329; Brunetti, A. E.; Carnevale Neto, F.; Vera, M. C.; Taboada, C.; Pavarini, D. P.; Bauermeister, A.; Lopes, N. P.; Chem. Soc. Rev. 2018, 47, 1574.

16. Goh, V. S. L.; Mok, C. K.; Chu, J. J. H.; Molecules 2020, 25 , 2796.

17. Gurung, S.; Nadeau, H.; Maxted, M.; Peregrine, J.; Reuter, D.; Norris, A.; Edwards, R.; Hyatt, K.; Singleton, K.; Papin, J. F.; Myers, D. A.; J. Virol. 2020, 94, e00058-20.

18. Rodriguez-Morales, A. J.; Cardona-Ospina, J. A.; RamirezJaramillo, V.; Gaviria, J. A.; González-Moreno, G. M.; Castrillón-Spitia, J. D.; López-Villegas, A.; Morales-Jiménez, E.; Ramírez-Zapata, V.; Rueda-Merchán, G. E.; Trujillo, A. M.; Tabares-Villa, F. A.; Henao-SanMartin, V.; Murillo-Garcia, D. R.; Herrera-Soto, J. A.; Buitrago-Cañas, M. L.; Collins, M. H.; Sepúlveda-Arias, J. C.; Londoño, J. J.; Bedoya-Rendón, H. D.; de Jesús Cárdenas-Pérez, J.; Olaya, S. X.; Lagos-Grisales, G. J.; Travel Med. Infect. Dis. 2018, 25, 20.

19. Rasmussen, S. A.; Jamieson, D. J.; Birth Defects Res. 2020, $112,1139$.

20. Cao, B.; Diamond, M. S.; Mysorekar, I. U.; J. Interferon Cytokine Res. 2017, 37, 287.

21. http://who.int/blueprint/priority-diseases/en/, accessed in December 2021.

22. Sánchez-Moreno, C.; A. Larrauri, J.; Saura-Calixto, F.; Food Res. Int. 1999, 32, 407.

23. Benzie, I. F.; Strain, J. J.; Anal. Biochem. 1996, 239, 70.

24. MacDonald, R. C.; MacDonald, R. I.; Menco, B. P. M.; Takeshita, K.; Subbarao, N. K.; Hu, L. R.; Biochim. Biophys. Acta, Biomembr. 1991, 1061, 297.

25. Drummen, G. P.; van Liebergen, L. C.; den Kamp, J. A. O.; Post, J. A.; Free Radical Biol. Med. 2002, 33, 473.

26. Miller, R. K.; Genbacev, O.; Turner, M. A.; Aplin, J. D.; Caniggia, I.; Huppertz, B.; Placenta 2005, 26, 439.

27. Delvecchio, R.; Higa, L. M.; Pezzuto, P.; Valadão, A. L.; Garcez, P. P.; Monteiro, F. L.; Loiola, E. C.; Dias, A. A.; Silva, F. J. M.; Aliota, M. T.; Caine, E. A.; Osorio, J. E.; Bellio, M.; O’Connor, D. H.; Rehen, S.; de Aguiar, R. S.; Savarino, A.; Campanati, L.; Tanuri, A.; Viruses 2016, 8, 322.

28. Li, C.; Zhu, X.; Ji, X.; Quanquin, N.; Deng, Y. Q.; Tian, M.; Aliyari, R.; Zuo, X.; Yuan, L.; Afridi, S. K.; Li, X. F.; Jung, J. U.; Nielsen-Saines, K.; Qin, F. X. F.; Qin, C. F.; Xu, Z.; Cheng, G.; EBioMedicine 2017, 24, 189. 
29. Shiryaev, S. A.; Mesci, P.; Pinto, A.; Fernandes, I.; Sheets, N.; Shresta, S.; Farhy, C.; Huang, C. T.; Strongin, A. Y.; Muotri, A. R.; Terskikh, A. V.; Sci. Rep. 2017, 7, 15771.

30. Oliveira, M. B. S.; Valentim, I. B.; Rocha, T. S.; Santos, J. C.; Pires, K. S. N.; Tanabe, E. L. L.; Borbely, K. S. C.; Borbely, A. U.; Goulart, M. O. F.; Ind. Crops Prod. 2020, 152, 112503.

31. Lanciotti, R. S.; Kosoy, O. L.; Laven, J. J.; Velez, J. O.; Lambert, A. J.; Johnson, A. J.; Stanfield, S. M.; Duffy, M. R.; Emerging Infect. Dis. 2008, 14, 1232.

32. GraphPad Prism, 8.3.0 software; GraphPad Software, San Diego, CA, USA, 2016

33. Crotti, A. E. M.; Lopes, J. L. C.; Lopes, N. P.; J. Mass Spectrom. 2005, 40, 1030.

34. Demarque, D. P.; Crotti, A. E. M.; Vessecchi, R.; Lopes, J. L. C.; Lopes, N. P.; Nat. Prod. Rep. 2016, 33, 432.

35. Moss, R.; Mao, Q.; Taylor, D.; Saucier, C.; Rapid Commun. Mass Spectrom. 2013, 27, 1815.

36. Yu, J.; Qi, J.; Zhang, L.; Yu, X.; Kong, Q.; Ren, X.; J. Chromatogr. B: Anal. Technol. Biomed. Life Sci. 2018, 1096, 88.

37. Sano, S.; Sugiyama, K.; Ito, T.; Katano, Y.; Ishihata, A.; J. Agric. Food Chem. 2011, 59, 6209.

38. Krambeck, K.; Oliveira, A.; Santos, D.; Pintado, M. M.; Silva, J. B.; Lobo, J. M. S.; Amaral, M. H.; Pharmaceuticals 2020, 13,73 .

39. Pan, Z. H.; Ning, D. S.; Fu, Y. X.; Li, D. P.; Zou, Z. Q.; Xie, Y. C.; Yu, L. L.; Li, L. C.; J. Agric. Food Chem. 2020, 68, 1555.

40. Uchida-Maruki, H.; Inagaki, H.; Ito, R.; Kurita, I.; Sai, M.; Ito, T.; Biol. Pharm. Bull. 2015, 38, 629.

41. Jiang, L.; Wang, Z.; Wang, X.; Wang, S.; Cao, J.; Liu, Y.; RSC Adv. 2020, 10, 4529.

42. les Parellada, F.; Deleruyelle, S.; Cassagnes, L. E.; Boutin, J. A.; Balogh, B.; Arbones-Mainar, J. M.; Biron, S.; Marceau, P.; Richard, D.; Nepveu, F.; Mauriège, P.; Carpéné, C.; Chem.-Biol. Interact. 2016, 258, 115.

43. Costa, F. P. D.; Puty, B.; Nogueira, L. S.; Mitre, G. P.; dos Santos, S. M.; Teixeira, B. J. B.; Kataoka, M. S. S.; Martins, M. D.; Barboza, C. A. G.; Monteiro, M. C.; Rogez, H.; de Oliveira, E. H. C.; Lima, R. R.; Antioxidants 2020, 9, 16.

44. Hosoda, R.; Hamada, H.; Uesugi, D.; Iwahara, N.; Nojima, I.; Horio, Y.; Kuno, A.; J. Pharmacol. Exp. Ther 2021, 376, 385.

45. Banik, K.; Ranaware, A. M.; Harsha, C.; Nitesh, T.; Girisa, S.; Deshpande, V.; Fan, L.; Nalawade, S. P.; Sethi, G.; Kunnumakkara, A. B.; Pharmacol. Res. 2020, 153, 104635.

46. Sáez, V.; Pastene, E.; Vergara, C.; Mardones, C.; HermosínGutiérrez, I.; Gómez-Alonso, S.; Gómez, M. V.; Theoduloz, C.; Riquelme, S.; von Baer, D.; Food Chem. 2018, 265, 101.

47. Son, Y.; Chung, H. T.; Pae, H. O.; BioFactors 2014, 40, 138.

48. Yang, C. X.; Zhou, J. T.; Li, Y. Z.; Hu, C. Q.; Planta Med. 2005, 71,569 .
49. Rivière, C.; Papastamoulis, Y.; Fortin, P. Y.; Delchier, N.; Andriamanarivo, S.; Waffo-Teguo, P.; Kapche, G. D. W. F.; Amira-Guebalia, H.; Delaunay, J. C.; Mérillon, J. M.; Richard, T.; Monti, J. P.; Bioorg. Med. Chem. Lett. 2010, 20, 3441.

50. Arraki, K.; Totoson, P.; Decendit, A.; Zedet, A.; Maroilley, J.; Badoc, A.; Demougeot, C.; Girard, C.; Molecules 2021, 26, 1694.

51. Hartogh, D. J. D.; Tsiani, E.; Biomolecules 2019, 9, 99.

52. Bueno, P. C. P.; Lopes, N. P.; ACS Omega 2020, 5, 1752.

53. Ramprasath, T.; Senthamizharasi, M.; Vasudevan, V.; Sasikumar, S.; Yuvaraj, S.; Selvam, G. S.; J. Physiol. Biochem. 2014, 70, 407.

54. Hernández-Aquino, E.; Muriel, P.; World J. Gastroenterol. 2018 , $24,1679$.

55. Wang, Q.; Ou, Y.; Hu, G.; Wen, C.; Yue, S.; Chen, C.; Xu, L.; Xie, J.; Dai, H.; Xiao, H.; Zhang, Y.; Qi, R.; Br. J. Pharmacol. 2020, 177, 1806.

56. Wang, R.; Wu, G.; Dai, T.; Lang, Y.; Chi, Z.; Yang, S.; Dong, D.; Exp. Ther. Med. 2020, 21, 66.

57. Syed, A. A.; Reza, M. I.; Shafiq, M.; Kumariya, S.; Singh, P.; Husain, A.; Hanif, K.; Gayen, J. R.; Life Sci. 2020, 257, 118118.

58. Kanashiro, A.; Kabeya, L. M.; Polizello, A. C. M.; Lopes, N. P.; Lopes, J. L. C.; Lucisano-Valim, Y. M.; Phytother. Res. 2004, $18,61$.

59. Xin, Y.-J.; Choi, S.; Roh, K.-B.; Cho, E.; Ji, H.; Weon, J. B.; Park, D.; Whang, W. K.; Jung, E.; Molecules 2021, 26, 255.

60. Ahmed, D.; Kumar, V.; Sharma, M.; Verma, A.; BMC Complementary Altern. Med. 2014, 14, 243.

61. Cibulski, S.; Teixeira, T. F.; Varela, A. P. M.; de Lima, M. F.; Casanova, G.; Nascimento, Y. M.; Tavares, J. F.; da Silva, M. S.; Sesterheim, P.; Souza, D. O.; Roehe, P. M.; Silveira, F.; Vaccine 2021, 39, 571.

62. Reginatto, F. H.; Gosmann, G.; Schripsema, J.; Schenkel, E. P.; Phytochem. Anal. 2004, 15, 195.

63. Gosmann, G.; Provensi, G.; Comunello, L. N.; Rates, S. M. K.; Rev. Bras. Biociências 2011, 9, 88.

64. Reginatto, F. H.; Kauffmann, C.; Schripsema, J.; Guillaume, D.; Gosmann, G.; Schenkef, E. P.; J. Braz. Chem. Soc. 2001, 12, 32 .

65. Fedoreyev, S.; Krylova, N.; Mishchenko, N.; Vasileva, E.; Pislyagin, E.; Iunikhina, O.; Lavrov, V.; Svitich, O.; Ebralidze, L.; Leonova, G.; Mar. Drugs 2018, 16, 509.

66. Almeida, L. T.; Ferraz, A. C.; Caetano, C. C. S.; Menegatto, M. B. S.; Andrade, A. C. S. P.; Lima, R. L. S.; Camini, F. C.; Pereira, S. H.; Pereira, K. Y. S.; Silva, B. M.; Perucci, L. O.; Talvani, A.; de Magalhães, J. C.; de Brito Magalhães, C. L.; Virus Res. 2020, 286, 198084.

67. de Oliveira, A. C.; Valentim, I. B.; Silva, C. A.; Bechara, E. J. H.; de Barros, M. P.; Mano, C. M.; Goulart, M. O. F.; Food Chem. 2009, 115, 469. 
68. de Souza, A. A. A.; Torres, L. R.; Lima, L. R. P.; de Paula, V.; Barros, J. J.; Bonecini-Almeida, M. G.; Waghabi, M. C.; Gardel, M. A.; Meuser-Batista, M.; de Souza, E. M.; Braz. J. Infect. Dis. 2020, 24,505

69. Li, J. W.; Vederas, J. C.; Science 2009, 325, 161.

70. Kao, J.-C.; HuangFu, W.-C.; Tsai, T.-T.; Ho, M.-R.; Jhan, M.-K.; Shen, T.-J.; Tseng, P.-C.; Wang, Y.-T.; Lin, C.-F.; PLoS Neglected Trop. Dis. 2018, 12, e0006715.

71. Haddad, J. G.; Koishi, A. C.; Gaudry, A.; dos Santos, C. N. D.; Viranaicken, W.; Desprès, P.; El Kalamouni, C.; Int. J. Mol. Sci. 2019, 20, 2382.

72. Carneiro, B. M.; Batista, M. N.; Braga, A. C. S.; Nogueira, M. L.; Rahal, P.; Virology 2016, 496, 215
73. Tan, C. W.; Sam, I.-C.; Chong, W. L.; Lee, V. S.; Chan, Y. F.; Antiviral Res. 2017, 143, 186.

74. Mounce, B. C.; Cesaro, T.; Carrau, L.; Vallet, T.; Vignuzzi, M.; Antiviral Res. 2017, 142, 148.

75. da Silva, S.; Martins, D. O. S.; Jardim, A.; Viruses 2018, 10, 255.

76. Cataneo, A. H. D.; Kuczera, D.; Koishi, A. C.; Zanluca, C.; Silveira, G. F.; de Arruda, T. B.; Suzukawa, A. A.; Bortot, L. O.; Dias-Baruffi, M.; Verri, W. A.; Robert, A. W.; Stimamiglio, M. A.; dos Santos, C. N. D.; Wowk, P. F.; Bordignon, J.; Sci. Rep. 2019, 9, 16348.
Submitted: September 8, 2021

Published online: January 5, 2022 